\title{
Distúrbios reprodutivos em cabras experimentalmente infectadas por Toxoplasma gondii *
}

\author{
Reproductive disorders in does experimentally infected \\ by Toxoplasma gondii
}

\author{
Flaviana Santos Wanderley, ${ }^{* *}$ Wagnner José Nascimento Porto, ${ }^{* * *}$ Diogo Ribeiro Câmara, ${ }^{* * *}$ \\ Andréa Alice da Fonseca Oliveira, ${ }^{* * *}$ Pomy Cássia Kim, ${ }^{* * *}$ Orestes Luís Souza Neto, ${ }^{* * *}$ \\ Érica Paes Barreto Xavier de Moraes, ${ }^{* * *}$ Rinaldo Aparecido Mota****
}

\begin{abstract}
Resumo
Objetivou-se descrever os distúrbios reprodutivos associados à infecção experimental por Toxoplasma gondii através da inseminação artificial com sêmen contaminado em quatro cabras no estágio crônico da infecção. As características do trato reprodutor foram avaliadas através de ultrassonografia transretal, visando o diagnóstico gestacional ou de desordens reprodutivas, após a infecção experimental. Ao final do experimento, os animais foram necropsiados e avaliações histopatológicas e PCR foram realizados. Dentre os animais infectados que exibiram mortalidade embrionária, duas apresentaram anestro e duas apresentaram repetição de estro, sendo que destas uma apresentou intervalos entre estros reduzido (sete dias) e outra em intervalo regular (21 dias). Todavia, ambas foram submetidas a monta natural durante os estros naturais subsequentes e não foi confirmada gestação até o final do experimento (90 dias). Duas cabras exibiram alterações nos exames de ultrassonografia, sendo identificadas um cisto ovariano, e uma hidrossalpinge, ambas confirmadas no exame post-mortem. As principais lesões microscópicas nesse grupo foram infiltração neutrofílica dos pulmões, glomerulonefrite intersticial e infiltração neutrofílica do fígado. O DNA de T. gondii foi encontrado nos órgãos (coração e cérebro) de três cabras. Em conclusão, cabras infectadas com sêmen contendo T. gondii no momento da inseminação artificial apresentam distúrbios reprodutivos na fase crônica da infecção que podem estar associados à toxoplasmose.
\end{abstract}

Palavras-chave: Caprinos, Infertilidade, Patologias Reprodutivas, Toxoplasmose.

\begin{abstract}
The aim of this study was to describe the reproductive disorders related to experimental infection by artificial insemination with semen contaminated with Toxoplasma gondii of four goats in the chronic phase of the infection. In the end of the study, the does were submitted to necropsy, and PCR and histopathological evaluations were performed. Among infected does that exhibited embryonic loss, two were in anestrus and two exhibited repeated estrus. One of the latter animals exhibited clinical signs of estrus at seven-day intervals, whereas the other had a 21-day estrous cycle. However, both does were naturally mated on subsequent natural estrous and were not able to get pregnant until the end of the experiment ( $90 \mathrm{~d})$. Two of the goats exhibited abnormalities in the ultrasound examinations, one of which was an ovarian cyst, while the other was a hydrosalpinx, both of which were confirmed in the post-mortem examination. The main microscopic injuries in this group were neutrophilic infiltration of the lungs, interstitial glomerulonephritis and neutrophilic infiltration of the liver. T. gondii DNA was found in the organs (heart and brain) of three does. In conclusion, does infected with Toxoplasma gondii in semen at the time of artificial insemination display reproductive disorders in the chronic phase of infection that might be associated with toxoplasmosis.
\end{abstract}

Keywords: Goat, Infertility, Reproductive Pathologies, Toxoplasmosis.

\section{Introduction}

Toxoplasmosis is a common cause of abortion in goats worldwide (DUBEY, 2010; ASGARI et al., 2011) since this species is susceptible to Toxoplasma gondii (DUBEY and ADAMS, 1990), but other animal species including humans are also susceptible (DUBEY, 2010). Natural infection during pregnancy can cause placental infection, embryonic loss, fetal mummification, abortion, stillbirth and neonatal mortality, all of which cause significant economic losses (DUBEY, 1982; DUBEY et al., 1986; DUBEY

*Recebido em 19 de agosto de 2018 e aceito em 5 de junho de 2019.

**Laboratory of Parasitic Infectious Diseases, University of Health Sciences of Alagoas, Maceió, CEP: 57010-382, Alagoas, Brazil;

${ }^{* * *}$ Course of Veterinary Medicine, Arapiraca Campus, Federal University of Alagoas, Viçosa, CEP 57700-000, Alagoas, Brazil;

****Laboratory of Infectious Contagious Diseases of Domestic Animals, Department of Veterinary Medicine, Rural Federal University of Pernambuco, Recife, CEP 52171-900, Pernambuco, Brazil;

Corresponding author: telephone +55(82)3315-6720; e-mail: flavianasw@hotmail.com 
AND ADAMS, 1990; CHANTON-GREUTMANN et al., 2002; DIAS AND FREIRE, 2005; SILVA FILHO et al., 2008).

A previous study by MORAES et al. (2010b) reported embryonic loss, anestrous, hydrometra, mucometra and follicular cysts in ewes experimentally infected with semen that had been contaminated with varying concentrations of tachyzoites of the CPG strain of Toxoplasma gondii (genotype III).

However, no studies have examined the chronic stages of reproductive disorders in goats experimentally contaminated with $T$. gondii. Thus, the aim of the present study was to diagnose and describe the effect of experimental infection with semen contaminated by $T$. gondii on the reproductive parameters of goats in the chronic stage of the infection.

\section{Case report}

All experimental procedures followed the guidelines of the International Guiding Principles for Biomedical Research Involving Animals and were approved by the Ethics Committee of the Federal Rural University of Pernambuco (CEUA-UFRPE - protocol 007/2010). The study was conducted at the São Luiz Farm, an experimental unit of the Federal University of Alagoas located at Viçosa-Alagoas, Brazil $\left(9^{\circ} 22^{`} \mathrm{~S} ; 36^{\circ} 14^{\prime} \mathrm{W}\right)$, between August and January.

The present study is a continuation of the experiment conducted by WANDERLEY et al. (2013), who described the results of Toxoplasma gondii infection (acute phase) in goats that had been experimentally infected with the CPG strain of Toxoplasma gondii (genotype III). In the resumption of this experiment, ten cycling (detecting by a teaser buck) kept under intensive system, multiparous and non-lactating native crossbreed goats, 3 to 4 years old, fed with Buffel grass (Cenchrus ciliaris L.), hay grass, concentrate and good quality water and mineral salt ad libitum were allocated into two groups (G1 and G2). The animals were clinically healthy and serologically negative for $T$. gondii and Neospora caninum (indirect immunofluorescence), as well as for Brucella abortus (buffered acidified antigen) and Chamidophyla abortus (complement fixation). All animals had good body condition and were dewormed and no clinical or ultrasonographic abnormality was detected before the experiment (live weight 35 $\pm 4 \mathrm{~kg}$ ).

The does had the estrous induced by administration of 0.15 mg of sodium cloprostenol (Ciosin, Shering Plough, São Paulo, $\mathrm{SP}$, Brazil) into the vulvar submucosa. A teaser was used to identify the females in estrus for a period of up to $72 \mathrm{hr}$ after administration of the prostaglandin. All does displayed behavioral signs of estrous (receptive to the buck, tail flagging, and bleating) and were inseminated with good quality fresh semen [diluted in skimmed milk extender (1:9, v:v), $12 \mathrm{~h}$ after estrous detection)] in the external cervical os. Does from $\mathrm{G} 1(\mathrm{n}=5)$ were inseminated with diluted semen, whereas the animals from $G 2(n=5)$ were inseminated with diluted semen plus $1 \times 10^{5}$ tachyzoites (CPG strain, genotype III, obtained from the suspension of washed intraperitoneal mice that had been previously infected with the strain).

The day of artificial insemination/experimental infection was considered D0. Between D15 and D60 the does were weekly monitored by transretal ultrasound evaluation using a multifrequency linear transducer (CTS 900V, SIUI, China) to diagnosis and monitoring reproductive abnormalities or pregnancy. Between D60 and D90, ultrasound assessments were performed at intervals of 15 days. After D90, animals from G2 group were euthanized, according to Resolution 1000 of the Federal Council of Veterinary Medicine (CFMV, 2012). Necropsies were performed, and sections of the liver, spleen, kidneys, bone marrow, brain, lung, heart, uterus and ovaries were collected and assessed microscopically.

In order to detect $T$. gondii DNA, the Polymerase Chain Reaction (PCR) was conducted on the organs (liver, spleen, kidneys, bone marrow, brain, lung, heart, uterus and ovaries) of goats. The tissue samples were subjected to DNA extraction using the "Qiagen DNA Easy Blood and Tissues Kit (Qiagen ${ }^{\circledR}$, Hilden, Germany), following the manufacturer's instructions. In the PCR, the primer pairs TOX4 (CGCTGCAGGGAGG AAGACGAAAGTTG) and TOX5 (GCTGCAGACACAGTGCATCTGGATT) were used, as described by HOMAN et al., (2000), amplifying a region of 529 base pairs. The amplification reactions were carried out in a final volume of $12.5 \mu \mathrm{l}$ containing $2.5 \mu \mathrm{l}$ of genomic DNA; $0.5 \mu \mathrm{l}$ of each primer (TOX4 andTOX5) to $10 \mu \mathrm{m} ; 2.5 \mu \mathrm{l}$ of Milli-Q ultrapure water and $6.25 \mu \mathrm{l}$ of Top Taq Master Mix (Qiagen), following the manufacturer's instructions. The thermal profile of the reaction steps was conducted in an XP Thermal Cycler (Bioer Technology Co., Binjiang, Hangzhou, China), consisting of a denaturation of the initial DNA at $94^{\circ} \mathrm{C}(7 \mathrm{~min})$ and followed by 35 cycles at $94^{\circ} \mathrm{C}$ for $1 \mathrm{~min}$ for denaturation, $60^{\circ} \mathrm{C}$ for $1 \mathrm{~min}$ for annealing, $72^{\circ} \mathrm{C}$ for $1 \mathrm{~min}$ for extension, and a final extension of $10 \mathrm{~min}$ at $72^{\circ} \mathrm{C}$. The amplified products were detected by agarose gel electrophoresis (2\%), stained with Blue Green (LGCt, Cotia, São Paulo, SP), visualized under ultraviolet light, and finally photo documented. The positive control used in the reaction was obtained through the suspension of washed intraperitoneal mice that had been previously infected with the $\mathrm{RH}$ strain.

The present report is focused on describe the chronic reproductive disorders observed in four of the five does of G2 group, who exhibited embryonic loss in the acute phase of the experimental infection with semen contaminated by tachyzoites after artificial insemination (one doe had a full-term pregnancy). The acute phase was considered between D0 and D28, when hyperthermia was detected (between D3 and D13) concurrently with Toxoplasma in the blood (PCR positive, D7), and antibody titers were still rising (indirect immunofluorescence), with stabilization at D28 (WANDERLEY et al., 2013), in accordance with previous reports (OWEN et al., 1998; NISHI et al., 2001; SANATA et al., 2010).

Two goats exhibited reproductive alterations during ultrasound evaluation in the chronic phase: in goat \#1, vesicular structures were visualized in the oviduct, exhibiting hypoechoic mucosa with an irregular surface and hypoechoic heterogeneous content, the largest measuring approximately $17 \mathrm{~mm}$ in diameter. This finding is compatible with unilateral salpingitis/ hydrosalpinx and was initially detected on D31, maintaining similar pattern during subsequent ultrasound evaluations and being confirmed later (D88) in the post-mortem examination. The goat \#2 presented embryonic loss between D35 and D49, followed by image compatible with an ovarian cyst, which was ultrasonographically identified from D63 on and confirmed during the necropsy (D90). Representative images of reproductive alterations detected by ultrasound in the chronic phase are shown (Figure 1). 


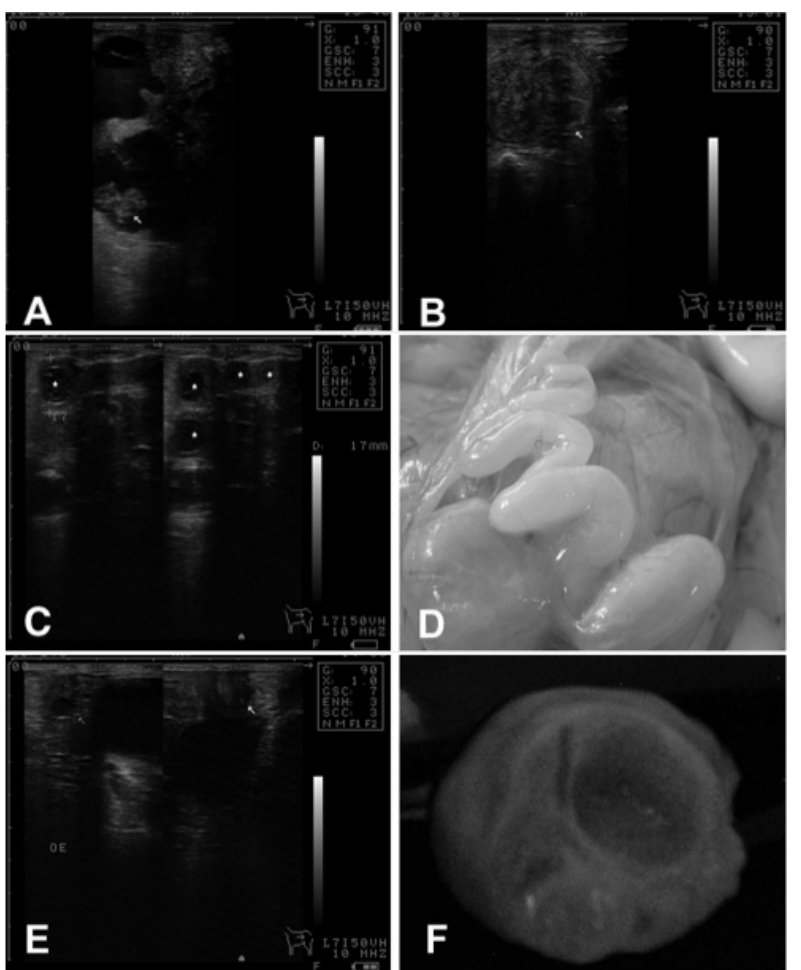

Figure 1: Reproductive disorders in goats during chronic phase of experimental infection with $T$. gondii through artificial insemination Confirmation of pregnancy on day 35 in goat \#2 (arrow indicates the embryo) (A); Absence of fetus (embryonic loss) on day 49 in goat \#2 (B); Oviduct of the goat \#1. Note the presence of vesicular structures exhibiting hypoechoic mucosa with an irregular surface and hypoechoic heterogonous content (asterisks), the largest these measuring approximately $17 \mathrm{~mm}$ in diameter. Findings compatible with salpingitis/hydrosalpinx (C); Necropsy photograph goat \#1 confirming ultrasound findings (D); Ultrasound image of the ovary in goat \#2 indicating an ovarian cyst (E); Necropsy photograph of the goat \#2 confirming ultrasound findings $(F)$. four goats were in anestrus and the other two exhibited repeated estrus. One of the latter animals exhibited clinical signs of estrus at seven-day intervals, whereas the other exhibited a 21-day estrus cycle (Table 1). Those with behavioral signs of estrous were naturally mated, but none were able to get pregnant.

The main microscopic injuries were neutrophilic infiltration of the lungs, interstitial glomerulonephritis and neutrophilic infiltration of the liver, with or without association with mononuclear infiltration. T. gondii DNA was found in the organs of three does (Table 1).

\section{Discussion}

The present study analyzed the effect of experimental infection with semen contaminated by Toxoplasma gondii on the reproductive parameters of goats in the chronic phase of infection. Similar findings were reported (MORAES et al., 2010a) in sheep that were inseminated with semen that had been contaminated with different concentrations of tachyzoites of the same strain used in the present study.

Embryonic loss and repeat breeding at irregular intervals were observed among the animals in the present study. These findings demonstrated that the parasite, introduced through semen, affected the initial phase of pregnancy and caused the death of the embryo. In two previous studies (DUBEY, 1981; 1989), goats were experimentally infected orally in different periods of gestation. Death and fetal loss were reported in all the goats after 50 days of pregnancy. MORAES et al. (2010b) also studied the chronic phase in relation to reproductive abnormalities and reported high rates of embryonic loss in sheep that were inseminated with semen that had been contaminated by tachyzoites of T. gondii.

Goats are more sensitive to T. gondii infection than sheep, and the stage of pregnancy at the time of primary infection could affect the overall result of the pregnancy. Embryonic loss is more

Table 1: Results of Toxoplasma gondii detection (PCR), histopathological and reproductive disorders of goats in the chronic phase of the infection by Toxoplasma gondii through artificial insemination

\begin{tabular}{|c|c|c|c|c|c|}
\hline Goat & $\begin{array}{c}\text { PCR } \\
\text { positive organs }\end{array}$ & $\begin{array}{l}\text { Gestation } \\
\text { Diagnosis }\end{array}$ & Histopathological Lesions & $\begin{array}{l}\text { Reproductive } \\
\text { behavior }\end{array}$ & $\begin{array}{l}\text { Ultrasound and } \\
\text { Necropsy }\end{array}$ \\
\hline 1 & Brain & - & $\begin{array}{l}\text { Lung: neutrophilic infiltration associated with focal } \\
\text { perivascular mononuclear infiltration } \\
\text { Kidney: interstitial glomerulonephritis } \\
\text { Liver: neutrophilic infiltration }\end{array}$ & $\begin{array}{l}\text { Repeated } \\
\text { Estrus } \\
\text { (7 days) }\end{array}$ & $\begin{array}{l}\text { Salpingits/ } \\
\text { Hydrosalpinx }\end{array}$ \\
\hline 2 & - & + & $\begin{array}{l}\text { Lung: neutrophilic infiltration and macrophages } \\
\text { Kidney: interstitial glomerulonephritis associated with } \\
\text { focal mononuclear infiltration in the cortex area }\end{array}$ & Anestrus & $\begin{array}{c}\text { Embryonic loss followed } \\
\text { by ovarian cyst }\end{array}$ \\
\hline 3 & $\begin{array}{l}\text { Brain/ } \\
\text { Heart }\end{array}$ & - & Lung: neutrophilic infiltration & Anestrus & - \\
\hline 4 & Heart & - & $\begin{array}{l}\text { Lung: neutrophilic infiltration } \\
\text { Kidney: interstitial glomerulonephritis } \\
\text { Liver: neutrophilic infiltration associated with diffuse } \\
\text { perivascular mononuclear infiltration }\end{array}$ & $\begin{array}{l}\text { Repeated } \\
\text { Estrus } \\
\text { (21 days) }\end{array}$ & - \\
\hline
\end{tabular}

After embryonic loss diagnosis, the four does were daily monitored for estrous detection with a deemed breeding sound buck, serologically negative for T. gondii until D90. Two of the common in the acute phase of infection in goats. Experimental studies have reported that goats infected by $T$. gondii may abort more than once (DUBEY, 1982). 
According to present data, reproductive abnormalities after Toxoplasma gondii experimental infection are not limited to the acute phase. This was confirmed in the present study by the two goats that exhibited clinical signs of estrus after embryonic loss and subsequently participated in natural mating for a second time, without getting pregnant. Moreover, the diagnosis of anestrus in two of the four goats that experienced embryonic loss was also an important finding, confirming that this type of pathology can be caused by the experimental infection of goats through semen.

With regards to the organs of does in the present study, the brain and the heart exhibited the highest degree of positive reactions for $T$. gondii in the PCR. A previous study (MORAES et al., 2010a) also used PCR and found DNA of the parasite in the fetal tissues of lambs whose mothers had been infected with semen contaminated with tachyzoites of $T$. gondii.

Anestrus, follicular cysts, and salpingitis/hydrosalpinx were detected in the chronic phase of infection. Although the results of the present study were not able to confirm the presence of $T$. gondii in the reproductive tract (using either PCR or histopathological tests), T. gondii DNA was detected by PCR in the uterus, ovaries and tubes of a naturally infected sheep (BEZERRA et al., 2014). Moreover, reproductive failure due to $T$. gondii was previously described by STAHL et al. (1994) among chronically infected female mice (cessation of estrous and constant diestrus cytology after one month), associated with marked infertility and uterine atrophy two months after infection, as well as impaired folliculogenesis. One study (MORAES et al., 2010b) also reported reproductive pathologies such as hydrometra, mucometra and follicular cysts in sheep that were infected with $T$. gondii using the same infection route as that of the present study. Other microscopic injuries observed in the present study were considered unrelated to toxoplasmosis.

The occurrence of hydrosalpinx in goats is low, ranging from 0.2 to $1.1 \%$ (AL-BAGGAL et al., 1993; MAIA et al., 2018a) and can be associated with microorganisms (BEENA et al., 2017) or hydrometra (MAIA et al., 2018b). Moreover, during the ultrasound evaluation of the doe \# 1 , the hypoechoic heterogonous content is suggestive of salpingitis, but histopathological diagnosis was compatible with hydrosalpinx. Because no disorders were ultrasonographically diagnosed before experimental infection and there was no segmental aplasia of the oviduct during post-mortem evaluation, it is possible that this doe had a secondary hydrosalpinx of inflammatory basis, with lumen stenosis (SCHLAFER E FOSTER, 2016), but the inflammatory characteristics were no longer detectable during histopathological evaluation.

In conclusion, does infected with Toxoplasma gondii in semen at the time of artificial insemination display reproductive disorders in the chronic phase of infection that might be associated with toxoplasmosis.

\section{Acknowledgements}

The authors thank the following: the Federal University of Alagoas (UFAL) for facilities; Dr. Roberta Lemos Freire (Federal University of Londrina) for providing the tachyzoites; the State of Alagoas Foundation for Research Support (FAPEAL - No. 20091133370-7) for providing the scholarship; and the State of Pernambuco Foundation for Research Support (FACEPE - APQ-1226-5.05/10) and CNPq (No. 305939/2011-4) for financial support for this project.

\section{References}

AL-BAGGAL, H.A.R.; AL-DAHASH, S.Y.A.; ALWAN, A.F. Macroscopic study of the female genital system in Iraq goats. Small Ruminant Research, v. 9, p. 341-346, 1993.

ASGARI, Q.; SARNEVESHT, J.; KALANTARI, M.; SADAT, S.J.; MOTAZEDIAN, M.H.; SARKARI, B. Molecular survey of Toxoplasma infection in sheep and goat from Fars province, Southern Iran. Tropical Animal Health and Production, v. 43, p. 389-392, 2011.

BEENA, V.; PAWAYIA, R.V.S.; GURURAJ, K.; SINGH, D.D.; MISHRA, A.K.; GANGWAR, N.K.; GUPTA, V.K.; SINGH, R.; SHARMA, A.K.; KARIKALAN, M.; KUMAR, A. Molecular etiopathology of naturally occurring reproductive diseases in female goats. Veterinary World, v. 10, n. 8, p. 964-972, 2017.

BEZERRA, M.J.G.; CRUZ, J.A.L.O.; KUNG, E.S.; SILVA, J.G.; SANTOS, E.S.; MORAES, E.P.B.X.; PINHEIRO-JÚNIOR, J.W.; MOTA, R.A. Occurrence of Toxoplasma gondii DNA in sheep naturally infected and slaughter in abattoirs in Pernambuco, Brazil. Pesquisa Veterinária Brasileira, v. 34, n. 4, p. 329-331, 2014.

CHANTON-GREUTMAN, H.; THOMA, R.; CORBOZ, L.; BOREL, N.; POSPISCHIL, A. Abortion in small ruminants in Switzerland: investigations during two lambing seasons (1996-1998) with special regard to chlamydial abortions. Schweizer Archiv für Tierheilkunde, v. 144, p. 483-492, 2002.
CFMV- Resolução n 1000 de 11 de maio de 2012 (2012) Dispõe sobre procedimentos e métodos de eutanásia em animais e dá outras providências. Available: www.cfmv.org.br. Accessed in14 june 2012.

DIAS, R.A.F; FREIRE R.L. Surtos de Toxoplasmose em seres humanos e animais. Semina: Ciências Agrárias, Londrina, v.26, p. 239-248, 2005.

DUBEY, J.P. Toxoplasma -Induced abortion in dairy goats. Journal of the American Veterinary Medical Association, v.178, p. 671-674, 1981.

DUBEY, J.P. Repeat transplacental transfer of Toxoplasma gondii in dairy goats. Journal of American Veterinary Medical Association, v. 180, p. 1220-1221, 1982.

DUBEY, J.P. Lesions in goats fed Toxoplasma gondii oocysts. Veterinary Parasitology, v. 32, p. 133-144, 1989.

DUBEY, J.P; MILLER, S; DESMONTS, G; THULLIEZ, P; ANDERSON, W.R. Toxoplasma gondii-induced abortion in dairy goats. Journal of the American Veterinary Medical Association, v. 188, p.159-162., 1986.

DUBEY, J.P.; ADAMS, D.S. Prevalence of Toxoplasma gondii antibodies in dairy goats from 1982 to 1984. Journal of the American Veterinary Medical Association, v. 196, p. 295-296, 1990. 
DUBEY, J.P. Toxoplasmosis in goats (Capra hircus). In: Toxoplasmosis of animals and humans. $2^{\text {nd }}$ ed. CRC Press: Boca Raton, Florida, 2010, p. 137-144.

HOMAN, W.L.; VERCAMMEN, M.; DE BRAEKELEER, J.; VERSCHUEREN, $\mathrm{H}$. Identification of a 200 - to 300 -fold repetitive 529 bp DNA fragment in Toxoplasma gondii, and its use for diagnostic and quantitative PCR. International Journal for Parasitology, v. 30, p.69-75, 2000.

MAIA, A.L.R.S.; BRANDÃO, F.Z.; SOUZA-FABJAN, J.M.G.; ARAÚJO, M.C.C.; SIQUEIRA, L.G.B; FACÓ, O.; FONSECA, J.F. Hydrosalpinx in dairy goats: occurrence, ultrasound diagnosis, macro- and microscopic characterization. Small Ruminant Research, v. 160, p. 5-11, 2018a.

MAIA, A.L.R.S.; BRANDÃO, F.Z.; SOUZA-FABJAN, J.M.G.; VEIGA, M.O.; BALARO, M.F.A.; SIQUEIRA, L.G.B.; PACÓ, O.; FONSECA, J.F. Hydrometra in dairy goats: ultrasonic variables and therapeutic protocols during the reproductive season. Animal Reproduction Science, v. 197, p. 203-211, 2018b.

MORAES, E.P.B.X.; BATISTA, A.M.; FARIA, E.B.; FREIRE, R.L.; FREITAS, A.C.; SILVA, M.A.R.; BRAGA, V.A.; MOTA, R.A. Experimental infection by Toxoplasma gondii using contaminated semen containing different doses of tachyzoites in sheep. Veterinary Parasitology, v. 170, p. 318-322, 2010a.

MORAES, E.P.B.X.; FREITAS, A.C; GOMES-FILHO, M.A; GUERRA, M.M.P.; SILVA, M.A.R.; PEREIRA, M.F; BRAGA, V.A.; MOTA, R.A. Characterization of reproductive disorders in ewes given an intrauterine dose of Toxoplasma gondii tachyzoites during the intrauterine insemination. Animal Reproduction Science, v.122, p. 36-41, 2010b
NISHI, S.M.; KASAI, N.; GENNARI, S.M. Antibody levels in goats fed Toxoplasma gondii oocysts. The Journal of Parasitology, v. 87 (2), p. 445-447, 2001.

OWEN, M.R.; CLARKSON, M.J.; TRESS, A.J. Acute phase toxoplasma abortion in sheep. Veterinary Record, v. 142, p. 480482, 1998.

SANTANA, L.F.L; COSTA, A.J.; PIERONI, J.; LOPES W.D.Z.; SANTOS, R.S.; OLIVEIRA, G.P.; MENDONÇA, R.P.; SAKAMOTO, C.A.M. Detection of Toxoplasma gondii in the reproductive system of male goats. Revista Brasileira de Parasitologia Veterinária, v. 19(3), p. 179,182, 2010.

SCHLAFER, D.H.; FOSTER, R.A. Female Genital System. In: Jubb, Kennedy \& Palmer's pathology of domestic animals. Volume 3. Sixth Edition. P. 359-423. 2016. 2456p.

STAHL, W.; KANEDA, Y.; NOGUCHI, T. Reproductive failure in mice chronically infected with Toxoplasma gondii. Parasitology Research, v. 80, p.22-28, 1994.

SILVA FILHO, M.F.; ERZINGER, E.; CUNHA, I.A.L.; BUGNI, F.M.; HAMADA, F.N.; MARANA, E.R.M; FREIRE, R.L; GARCIA, J.L.; NAVARRO, I.T. Toxoplasma gondii: abortion outbreak in a goatherd from Southern Brazil. Semina, v. 29, p. 887, 2008.

WANDERLEY, F.S.; PORTO, W.J.; CÂMARA, D.R.; DA CRUZ, N.L.; FEITOSA, B.C.; FREIRE, R.L.; DE MORAES, E.P.; MOTA, R.A. Experimental vaginal infection of goats with semen contaminated with the "CPG" strain of Toxoplasma gondii. The Journal of Parasitology, v. 99, p. 610-613, 2013. 